\title{
Efficacy of an Asynchronous Online Preparatory Chemistry Course: A Post-hoc Analysis
}

Grace Henbest, Kiana Mortezaei, Teresa Alvelais, Courtney Murphy, and Jack F. Eichler* Department of Chemistry, University of California, Riverside, 501 Big Springs Road, Riverside, CA 92521, USA.

\begin{abstract}
In an ongoing effort to increase student retention and success in the undergraduate general chemistry course sequence, a fully online preparatory chemistry course was developed and implemented at a large public research university. To gain insight about the efficacy of the online course, post-hoc analyses were carried out in which student performance on final exams, and performance in the subsequent general chemistry course were compared between the online cohort and a previous student cohort who completed the preparatory chemistry course in a traditional lecture format. Because the retention of less academically prepared students in STEM majors is a historical problem at the institution in which the online preparatory chemistry course was implemented, post-hoc analyses were also carried out to determine if this at-risk group demonstrated similar achievement relative to the population at large. Multiple linear regression analyses were used to compare final exam scores and general chemistry course grades between the online and in-person student cohorts, while statistically controlling for incoming student academic achievement. Results from these analyses suggest the fully online course led to increased final exam scores in the preparatory course (unstandardized $B=8.648, p<0.001$ ) and higher grades in the subsequent general chemistry course (unstandardized $B=0.269, p<0.001$ ). Notably, students from the lowest quartile of incoming academic preparation appear to have been more positively impacted by the online course experience (preparatory chemistry final exam scores: unstandardized $B=11.103, p<0.001$; general chemistry course grades: unstandardized $B=0.323$, $p=0.002$ ). These results suggest a fully online course can help improve student preparation for large populations of students, without resulting in a negative achievement gap for less academically prepared students. The structure and implementation of the online course, and the results from the post-hoc analyses will be described herein.
\end{abstract}

Keywords: First-Year Undergraduate/General, Computer-Based Learning, Curriculum, Internet/Web-Based Learning, Enrichment/Review Materials 


\section{INTRODUCTION}

In response to the persistent need to improve retention and interest in STEM disciplines, there is an ongoing effort at undergraduate institutions to ensure students are adequately prepared for college-level science and math. ${ }^{1}$ Because the year-long general chemistry sequence is a common barrier for student success in STEM fields, ${ }^{2}$ preparatory courses or summer bridge programs designed to teach the fundamental skills required for general chemistry are common in undergraduate chemistry programs. ${ }^{3}$ At the University of California-Riverside (UCR), all students in the College of Natural and Agricultural Sciences (CNAS) are required to take general chemistry, and the use of general chemistry as a prerequisite for other science courses is also common across the University of California (UC) system. The increasing need to ensure incoming first-year students are adequately prepared for this course is partly evidenced by the fact that within the UC system, six out of the nine undergraduate campuses offer an in-person preparatory chemistry course. ${ }^{4}$ At UCR, the preparatory chemistry course has been in the university course catalog for more than a decade, but has been offered intermittently depending on personnel and resource availability.

Justification for offering preparatory courses or summer bridge programs is rooted in the chemical education literature, which suggests that students who participate in these types of programs perform better, on average, in subsequent chemistry courses than students who do not receive this additional preparation. ${ }^{1,5,6}$ Eitemüller and Habig report that a two-week in-person bridge course led to short-term improvements in content knowledge for students with low prior chemistry knowledge, whereas students with high prior content knowledge appeared to make longer-term performance gains in the subsequent general chemistry course. ${ }^{5}$ Botch and coworkers report that an optional 20-hour online bridge course helped self-selected high achieving students achieve improved performance in general chemistry relative to non-participants, however it is noted less-prepared students did not opt into the program at significant levels. ${ }^{1}$ Though the positive impact to performance in general chemistry for specific types of students appear to be clearly evidenced, the benefits of these preparatory experiences are counterbalanced by the fact they require additional departmental resources, and academic-year prep courses can lead to "off sequence" populations of students who are less likely to persist in their STEM major if these courses are offered in the fall term. ${ }^{7}$ 
Due to the constraints in resources and desire to create a course that can be offered in the summer as a bridge-type of experience for incoming first-year students, efforts were initiated to create an online version of our traditional in-person preparatory chemistry course. The use of online instruction is often viewed by faculty with a skeptical eye, especially among older and more experienced instructors. ${ }^{8}$ However, there is a growing body of evidence suggesting online instruction, when implemented with full-time residential college students enrolled in four-year degree programs, performs as well and often better than equivalent traditional instruction. ${ }^{9,10}$ The body of research looking at the efficacy of online instruction in undergraduate chemistry is less well developed, though the recent report by Faulconer and coworkers suggests an online implementation of a general chemistry course including both lecture and lab compares favorably to the equivalent in-person course. ${ }^{11}$ Regarding online preparatory chemistry courses, the findings from Botch and coworkers described above provide some evidence that an online bridge course can positively impact student performance in general chemisry. ${ }^{1}$ Additionally, the study reported by Docktor and co-workers suggests an online summer bridge intervention positively impacted student performance in the subsequent fall-term general chemistry course. More specifically, it was found that students who completed self-paced modules within the adaptive-responsive ALEKS learning system performed on par with students who placed directly into the general chemistry course, and performed significantly better on the general chemistry course final exam compared to students who took the traditional in-person preparatory chemistry course. ${ }^{3}$

The positive outcomes in online learning environments described above can be framed in Mayer's cognitive theory of multimedia learning. ${ }^{12}$ The cognitive theory of multimedia learning purports that gaining new knowledge through online instruction can effectively take place if one receives information from two sensory platforms: auditory and visual. This information is then organized and works in conjunction with prior knowledge that is retrieved from one's long term memory to foster meaningful learning as opposed to rote learning, and helps overcome the limitations of one's working memory capacity. Mayer also outlines how the research on multimedia learning can inform instructional design, and lists the reduction of extraneous processing, managing essential processing, and fostering generative processing as guiding principles. ${ }^{12}$ When properly designed, online instruction has the potential to avoid the cognitive overload that is generally associated with student learning in traditional in-person lecture environments. Despite the potential benefits of asynchronous online learning (asynchronous is 
defined as online learning in which students work individually at their own pace), there are potential gaps in the research that should be considered by both educational researchers and practitioners of online instruction. In particular, Mayer notes there may be boundary conditions for the impact of online instruction. Foundational research needs to be broadened to help determine how different types of multimedia instructional methods impact different types of learners (i.e., low versus high knowledge learners), how online instruction might be tailored for different types of learning objectives (i.e, conceptual learning versus algorithmic problem solving), and how online learning is able to affect transfer of knowledge rather than retention of knowledge. ${ }^{12}$ Instructors should be cognizant of these boundary conditions when designing and implementing online courses.

In the present report, the implementation of a fully online, asynchronous preparatory chemistry course will be described. Because logistical constraints did not allow for the course to be offered in a summer bridge format for incoming first-year students, it was initially offered during the fall term analogous to previous in-person offerings of the course. It is also noted the course was not designed and implemented within the framework of a research study in which specific instructional interventions were compared to a contemporaneous "teaching as usual" control. The goal was to structure the online learning environment in a way that was most likely to avoid logistical and technical roadblocks, while hopefully leading to similar student performance outcomes as previous offerings of the in-person version of the course. Because the corresponding author was the instructor of record for both the new online course and the previous in-person version of the course, it was possible to carry out a post-hoc analysis in which performance outcomes were compared between the two student cohorts. The results of this analysis will be described and discussed within the context of the previous research that investigated the efficacy of preparatory chemistry courses, and within the context of the cognitive theory of multimedia learning.

\section{METHODS}

\section{Course Structure}

The analysis described herein was conducted to determine the impact a new asynchronous preparatory chemistry (prep chem) course had on student performance, both on the final exam score in the prep chem course and on the final course grade in the subsequent general chemistry course (CHEM 001A). The online prep chem course was taught in the fall of 2018 (this student 
cohort will be designated F18), and was compared to a student cohort who took the traditional inperson prep chem course the previous fall (this cohort will be designated F17). The F17 course met twice a week for 50 minutes, and included weekly 120-minute recitation sessions facilitated by graduate student teaching assistants (TAs). The assignments in the F17 traditional lecture consisted of two midterms, a final exam, and weekly online quizzes. The final exam for the inperson course was a three-hour exam that consisted of 40 questions worth a total of 400 points, and no additional graded homework was assigned aside from the weekly online quizzes in the course management system. Students were given extra credit for attending the weekly discussion group sections, in which group problem solving worksheets were completed under the guidance of a graduate student TA, but these activities were not graded or collected. Overall, the course was graded on a pass-fail basis in which students were awarded three units of free elective course credit. The schedule of topics and full description of the course are provided in the attached Supporting Information.

In lieu of attending the in-person lectures, students in the F18 course were directed to complete online video tutorials in a self-paced manner and complete the associated online quizzes within the course management system, and the in-person discussion group sections were eliminated from the F18 online course. Though the individual modules were self-paced, these online activities had deadlines that were scheduled approximately every two weeks to ensure students did not attempt to complete all of the course content in a condensed time frame at the end of the term. The weekly

Table 1: Online Modules for preparatory chemistry course.

\begin{tabular}{|c|l|l|l|}
\hline Unit & Dates & Topics & Activities \\
\hline 1 & Oct. 1-14 & $\begin{array}{l}\text { Matter, Measurements, and } \\
\text { Dimensional Analysis }\end{array}$ & 1. Online lectures/iLearn quiz \\
\hline 2 & Oct. 15-28 & Atomic Structure & 1. Online lectures/iLearn quiz \\
\hline 3 & Oct. 29-Nov. 11 & Electronic Structure & $\begin{array}{l}\text { 1. Online lectures/iLearn quiz } \\
\text { 2. Online iLearn midterm exam }\end{array}$ \\
\hline $\begin{array}{c}\text { Midterm } \\
\text { Exam }\end{array}$ & Due Nov. 16 & Units 1-3 & 1. Online lectures/iLearn questions \\
\hline 4 & Nov. 12-25 & Chemical Reactions & Online lectures/iLearn questions \\
\hline 5 & Nov. 25-Dec. 10 & Solutions and Miscellaneous \\
\hline $\begin{array}{l}\text { Final } \\
\text { Exam }\end{array}$ & Due Dec. 13 & Units 1-5 & \\
\hline
\end{tabular}


quizzes from F17 were adapted for use in the F18 online course, and quizzes within each unit were combined into one quiz that was due at the end of each module (see Table 1 for the schedule of topics and module deadlines). The online video tutorials were produced using a learning glass system that incorporated a picture-in-picture graphical feature. ${ }^{13}$ A screenshot of a sample learning glass video is shown in Figure 1.

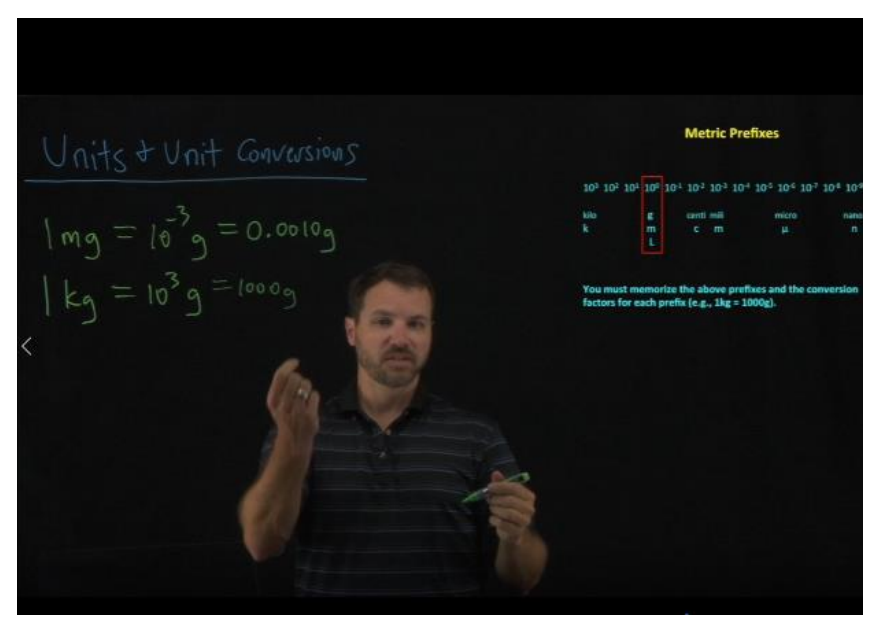

Figure 1: Screenshot of learning glass video used in the online prep chem course (F18). All video tutorials were produced using the learning glass system. ${ }^{13}$
In addition to the bi-weekly quizzes, the F18 online course had one midterm and a final exam. The midterm exam for the F18 online course was not completely analogous to the F17 midterms since it covered a different set of topics, however midterms from both the F17 and F18 courses consisted of multiple-choice questions that assessed computational skills and basic conceptual knowledge retention. In order to mitigate unapproved collaboration among students on the exams, the ProctorU online exam proctoring service was used for the midterm and final exam. ${ }^{14}$ Students could arrange to take the exams at home or in an on-campus study room, but the proctoring service verified students identities and monitored the students' work flow through the computer web cam, and prevented students from opening up any programs aside from the online test interface in the course management system. The campus library at UCR provides free access to laptop computers, which ensured students had access to computers that were compatible with the ProctorU service. The proctoring service did have an associated cost that increased based on the length of the exam, therefore the final exam for the online course was scheduled as a two-hour exam that consisted of 30 multiple-choice questions, worth a total of 400 points. Though the F18 final exam had fewer questions, this exam was created using a subset of questions from the F17 final (the F17 final was not distributed to students, therefore students in the F18 course did not have access to the prior exam). The online prep chem course was also graded on a pass-fail basis, but was worth only two units of free elective course credit since it did not include the additional weekly discussion group 
sessions. The full course description is provided in the attached Supporting Information. It is noted that both the in-person (F17) and online (F18) courses used the freely available OpenStax textbook, ${ }^{15}$ and both courses were focused on skill development rather than higher order reasoning skills. In particular, considerable time was devoted to strengthening skills related to unit conversions, dimensional analysis, and the introduction to lower order learning objectives associated with atomic theory and electronic structure.

In both the F17 and F18 terms, the prep chem course was part of the CNAS Scholars Learning Communities (LCs). Students who joined the LC and were eligible to take the prep chem course would register for the class as part of their LC block of classes. Approximately $50 \%$ of incoming CNAS first-year students who did not place directly into the regular general chemistry course were enrolled in the prep chem course through the LC in both F17 and F18, and over $90 \%$ of students in the F17 and F18 cohorts were enrolled in a first-year learning community. The students who were placed into the prep chem course but did not take the course in the fall term could not be tracked for this post-hoc analysis.

The analysis described below includes tracking the final student grades in the subsequent winter-term CHEM 001A courses (winter-term 2018 = W18; winter-term $2019=\mathrm{W} 19$ ). Unfortunately, it was not possible to track the matriculation of the F17 and F18 student cohorts into the specific CHEM 001A sections. There were three CHEM 001A sections of approximately 280-300 students in both the W18 and W19 terms, with three instructors teaching the three sections in W18 and two instructors teaching the three sections in W19 (one instructor taught two separate sections; the instructor who taught one section of CHEM 001A in W18 and also taught one section W19). Though there was some inherent instructor variability across the W18 and W19 cohorts, all sections were taught using the same textbook, all instructors used the same online homework system, and all instructors taught using predominantly traditional lecture techniques (i.e., there was no significant use of collaborative group learning or active learning). The instructors from W18 and W19 based their final grades on the online homework, 2-3 midterm exams, and a comprehensive final exam (all midterm exams and final exams were multiple choice, but did vary between instructors). The percentages of students who did not achieve a grade of $\mathrm{C}$ - or higher ranged from 10-20\% for all sections across the W18 and W19 terms (the success rates were not reported for each instructor, but the department reported this data for all sections in an anonymous fashion). 


\section{Statistical Analyses}

The post-hoc comparison of student performance outcomes between the F17 and F18 cohorts was approved by the UCR Institutional Review Board (IRB) as an exempt study under protocol HS-19-296. Because the online course was not implemented within a typical experimental or quasi-experimental research design, multiple regression analyses were used to model the impact of the online course on performance outcomes relative to the previous in-person course, while statistically controlling for incoming academic preparation, gender, and ethnicity. Student populations from the F18 online course were considered the "treatment" group, whereas populations from the F17 in-person course were considered the "control" group. These independent variables were dummy coded, in which $1=$ "online course participant" and 0 = "inperson participant," allowing for the determination of whether the online course significantly related to the prep chem final exam or CHEM 001A course grade dependent variables. Linear regression models that included ethnicity and gender as independent variables were also dummy coded $(1=$ female, $0=$ male; $1=$ specific racial identity; $0=$ other $)$. As described by Murnane and Willett, a regression equation was used to measure the impact of participating in the online prep chem course. ${ }^{16}$ This model accounts for the various independent variables, and calculates their effect on the dependent variable (see Equation 1).

$$
\left.\mathrm{y}=\mathrm{a}+\mathrm{b}_{1} \mathrm{x}_{1}+\mathrm{b}_{2} \mathrm{x}_{2}+\ldots+\mathrm{b}_{\mathrm{k}} \mathrm{x}_{\mathrm{k}}+\varepsilon \quad \text { (Equation } 1\right)
$$

All multiple linear regression analyses were carried out using the SPSS Statistics 24 software package ${ }^{17}$ For the analyses in which the prep chem final exam score was included as the dependent variable, the scores for the F18 and F17 were reported as a score out of 100 points. For the analyses in which the CHEM 001A course grade was included as the dependent variable, the course grade was reported as a numerical GPA quality point (on a scale from 0-4; this scale includes different point values for $+/$ - letter grades). Because the retention and four-year graduation rates of students in the UCR College of Natural and Agricultural Sciences continues to lag behind those observed in the College of Humanities and Social Sciences, separate analyses were carried out to determine if the F18 online prep chem had similar impact on less academically prepared students relative to the overall class population (math SAT scores were used to identify the lowest quartile of students). All analyses were performed under the working null hypothesis that states "there is no relationship between participation in the different type of prep chem course and the performance-based dependent variable" (i.e., prep chem final exam score or CHEM 001A course grade). Finally, the 
statistical power and effect sizes for the multiple linear regression analyses associated with the total class population and lowest quartile of academically prepared students were calculated as described by Cohen (1988). ${ }^{18}$

\section{RESULTS}

The descriptive statistics for the F17 in-person and F18 online student cohorts are summarized in Table 2. The gender and demographic makeup of the two cohorts were similar, and were representative of the campus-wide undergraduate population. ${ }^{19}$ The F18 online prep chem cohort appeared to have higher final exam scores in the prep chem course and higher grades in CHEM 001A than the F17 in-person cohort, though it appeared the high school GPA and math SAT scores were also higher for the F18 online cohort.

Because the incoming academic preparation of the F18 online cohort may have been higher than the F17 in-person cohort, these independent variables were included in the multiple linear regression models as described above. The analyses comparing the performance of the entire class course are summarized in Tables 3 and 4, respectively. The regression analysis in which classroom participation was included as the independent variable, and prep chem final exam scores were included as the dependent variable indicates the F18 online cohort had significantly higher scores than the F17 in-person cohort (Table 3). Because the class participation independent variables were dummy coded ( $1=\mathrm{F} 18$ online course; $0=\mathrm{F} 17$ in-person course $)$, the unstandardized $B$ coefficient represents the change statistic for the dependent variable. Therefore, it was found students in the F18 online course performed, on average, 8.6 points higher on the prep chem final than students in the F17 in-person course, while holding constant the independent variables related to incoming academic preparation and student demographic identity. This difference was significant to the $p=$ 0.001 level (unstandardized $B=8.637, p<0.001$; see Table 3). The multiple linear regression also confirms previous findings that indicate high school GPA and math SAT scores are positively related to student performance on the prep chem final exam, ${ }^{20,21}$ as these two independent variables had positive unstandardized $B$ coefficients that were significant to the $p=0.05$ level and $p=0.001$ level, respectively (see Table 3; it is noted the unstandardized $B$ coefficients for these continuous 
Table 2: Descriptive statistics; student cohorts from F17 in-person and F18 online prep chem courses.

\begin{tabular}{|c|c|c|}
\hline Statistic & F17 $(n=408)$ & F18 $(n=463)$ \\
\hline Number of Students in First-year Learning Community & $396(97 \%)$ & $435(94 \%)$ \\
\hline Average Prep Chem Final Exam Score & $276 \pm 51$ (out of 400 points) & $314 \pm 51$ (out of 400 points) \\
\hline Average Prep Chem Final Exam Percentage & $69.0 \%$ & $78.6 \%$ \\
\hline Number of Students who Failed Course & $23(5.6 \%)$ & $21(4.6 \%)$ \\
\hline Number of Students who Withdrew from Course & $2(0.49 \%)$ & $2(0.43 \%)$ \\
\hline $\begin{array}{c}\text { Average General Chemistry (CHEM 001A) Grade (GPA } \\
\text { quality point on } 0-4 \text { scale) }\end{array}$ & $2.58 \pm .83$ & $2.93 \pm .63$ \\
\hline Average HS GPA & $3.72 \pm 0.45$ & $3.80 \pm 0.24$ \\
\hline Average SAT Math & $554 \pm 57$ & $572 \pm 62$ \\
\hline Male & $\mathrm{n}=134(33 \%)$ & $\mathrm{n}=151(33 \%)$ \\
\hline Female & $\mathrm{n}=267(65 \%)$ & $\mathrm{n}=307(66 \%)$ \\
\hline Not reported & $\mathrm{n}=7(2 \%)$ & $\mathrm{n}=5(1 \%)$ \\
\hline Asian & $\mathrm{n}=132(32 \%)$ & $\mathrm{n}=160(35 \%)$ \\
\hline White & $\mathrm{n}=51(13 \%)$ & $\mathrm{n}=49(10 \%)$ \\
\hline Hispanic or Latino & $\mathrm{n}=191(47 \%)$ & $\mathrm{n}=204(44 \%)$ \\
\hline Multiracial & $\mathrm{n}=21(5 \%)$ & $\mathrm{n}=30(6.5 \%)$ \\
\hline Black or African American & $\mathrm{n}=8(2 \%)$ & $\mathrm{n}=13(3 \%)$ \\
\hline Native Hawaiian/Pacific Islander & $\mathrm{n}=1(0.2 \%)$ & $\mathrm{n}=1(0.2 \%)$ \\
\hline Nonresident & $\mathrm{n}=1(0.2 \%)$ & $\mathrm{n}=2(0.4 \%)$ \\
\hline Unknown & $\mathrm{n}=3(0.6 \%)$ & $\mathrm{n}=4(0.9 \%)$ \\
\hline
\end{tabular}

variables represent the unit increase in the dependent variable for every unit increase in the independent variable).

The regression analysis in which classroom participation was included as the independent variable, and CHEM 001A course grades were included as the dependent variable, indicates the F18 online cohort also had significantly higher general chemistry grades than the F17 in-person cohort (Table 4). It was found students in the F18 online course earned course grades that were, on average, 0.27 GPA quality points higher than students in the F17 in-person course, while 
Table 3: Multiple linear regression analysis determining the impact of course participation on prep chem final exam score for the total student population. Independent variable ("group") = class participation ( $1=$ online, $0=$ in-person); dependent variable $=$ prep chem final exam score (final exam scores were reported as scores out 100 points); F18 online prep chem course: $n=463$; F17 in-person course: $n=408{ }^{a}$

\begin{tabular}{|c|c|c|c|c|c|c|c|}
\hline \multirow[b]{2}{*}{ Independent Variable } & \multicolumn{2}{|c|}{$\begin{array}{l}\text { Unstandardized } \\
\text { Coefficients }\end{array}$} & \multirow{2}{*}{$\begin{array}{c}\begin{array}{c}\text { Standardized } \\
\text { Coefficients }\end{array} \\
\text { Beta }\end{array}$} & \multirow[b]{2}{*}{$t$} & \multirow[b]{2}{*}{$p$} & \multicolumn{2}{|c|}{$\begin{array}{l}\text { 95.0\% Confidence } \\
\text { Interval for } B\end{array}$} \\
\hline & $\boldsymbol{B}$ & $\begin{array}{l}\text { Std. } \\
\text { Error }\end{array}$ & & & & $\begin{array}{l}\text { Lower } \\
\text { Bound }\end{array}$ & $\begin{array}{l}\text { Upper } \\
\text { Bound }\end{array}$ \\
\hline (Constant) & 39.540 & 8.199 & & 5.02 & $<0.001$ & 23.447 & 55.632 \\
\hline $\begin{array}{l}\text { Group }(1=\mathrm{W} 18 \text { online; } \\
0=\mathrm{W} 17 \text { in-person })\end{array}$ & 8.648 & 0.813 & 0.343 & 10.638 & $<0.001$ & 7.052 & 10.243 \\
\hline HS_GPA & 3.580 & 1.671 & 0.071 & 2.142 & 0.032 & 0.300 & 6.860 \\
\hline SAT_MATH & 0.030 & 0.007 & 0.145 & 4.388 & $<0.001$ & 0.017 & 0.044 \\
\hline
\end{tabular}

a. $\mathrm{R}=0.400 ; \mathrm{R}^{2}=0.160$; Adjusted $\mathrm{R}^{2}=0.157$; Standard Error of the Estimate $=11.56 ; \mathrm{f}^{2}$ effect size $=0.132$ (see Supplemental Table 3 for effect size and estimated power calculations).

Table 4: Multiple linear regression analysis determining the impact of course participation on general chemistry course grade for the total student population (general chemistry was taken in the subsequent quarter after the prep chem course). Independent variable ("group”) = class participation $(1=$ online, $0=$ in-person $)$; dependent variable = course grade (expressed as 0-4 GPA quality point); F18 online prep chem course: $\mathrm{n}=463$; F17 in-person course: $\mathrm{n}=$ $408 .^{\mathrm{a}}$

\begin{tabular}{|c|c|c|c|c|c|c|c|}
\hline \multirow[b]{2}{*}{ Independent Variable } & \multicolumn{2}{|c|}{$\begin{array}{l}\text { Unstandardized } \\
\text { Coefficients }\end{array}$} & \multirow{2}{*}{$\begin{array}{c}\begin{array}{c}\text { Standardized } \\
\text { Coefficients }\end{array} \\
\text { Beta }\end{array}$} & \multirow[b]{2}{*}{$t$} & \multirow[b]{2}{*}{$p$} & \multicolumn{2}{|c|}{$\begin{array}{l}\text { 95.0\% Confidence } \\
\text { Interval for } B\end{array}$} \\
\hline & $\boldsymbol{B}$ & $\begin{array}{l}\text { Std. } \\
\text { Error }\end{array}$ & & & & $\begin{array}{l}\text { Lower } \\
\text { Bound }\end{array}$ & $\begin{array}{l}\text { Upper } \\
\text { Bound }\end{array}$ \\
\hline (Constant) & -0.541 & 0.506 & & -1.069 & 0.285 & -1.533 & 0.452 \\
\hline $\begin{array}{c}\text { Group }(1=\text { W18 online; } 0= \\
\text { W17 in-person })\end{array}$ & 0.269 & 0.050 & 0.179 & 5.370 & $<0.001$ & 0.171 & 0.368 \\
\hline HS_GPA & 0.435 & 0.103 & 0.144 & 4.216 & $<0.001$ & 0.232 & 0.637 \\
\hline SAT_MATH & 0.003 & 0.000 & 0.218 & 6.397 & $<0.001$ & 0.002 & 0.004 \\
\hline
\end{tabular}

a. $\mathrm{R}=0.321 ; \mathrm{R}^{2}=0.103$; Adjusted $\mathrm{R}^{2}=0.100$; Standard Error of the Estimate $=0.713 ; \mathrm{f}^{2}$ effect size $=0.0334$ (see Supplemental Table 2 for effect size and estimated power calculations). 
holding constant the independent variables related to incoming academic preparation. This difference was significant to the $p=0.001$ level (unstandardized $B=0.269, p<0.001$; see Table 4). High school GPA and math SAT also appeared to have a positive relationship with CHEM 001A course grade, with both independent variables having positive unstandardized $B$ coefficients that were significant to the $p=0.001$ level ( $p<0.001$ for both variables; see Table 4 ). Linear regression models were also created in which gender and ethnic identity were included as independent variables (see Supplemental Tables 1 and 2). These covariates did not appear to have a significant relationship to the prep chem final exam scores or CHEM 001A course grades, as none of these independent variables had unstandardized $B$ coefficients that were significant at the $p=0.05$ level. Additionally, the explanatory power of neither model improved significantly when the gender and ethnic identity variables were included (i.e., the adjusted $\mathrm{R}^{2}$ did not increase significantly when these additional independent variables were included in the model; see Supplemental Tables 1 and 2), therefore the models described in Tables 3 and 4 were used in the final analysis.

The multiple linear regression analyses summarized in Tables 3 and 4 suggest the null hypothesis stating "there is no relationship between participation in the different type of prep chem course and the performance-based dependent variable" can be rejected for both dependent variables. Despite the apparent significance of the impact of the online prep chem course on student performance, it was prudent to determine the effect size and statistical power of these analyses. The $\mathrm{f}^{2}$ effect size and statistical power for multiple regression analyses were calculated as previously described by Cohen (see Supplemental Tables 3 and 4 for descriptions of these calculations, and Chapter 9 in Statistical Power Analysis for the Behavioral Sciences). ${ }^{18}$ The $\mathrm{f}^{2}$ effect size, which indexes the degree of departure from the null hypothesis (i.e., the degree of departure from no treatment effect), was found to be 0.132 and 0.0334 , respectively for prep chem final exam score and CHEM 001A course grade analyses. Cohen designates an $\mathrm{f}^{2}$ effect size of 0.02 as small, 0.15 as medium, and 0.35 as large. ${ }^{18}$ The statistical power, the probability the statistical test can lead one to reject the null hypothesis, was determined to be greater than 0.995 and approximately 0.91, respectively, for the prep chem final exam score and CHEM 001A course grade analyses (the generally accepted value for statistical power is 0.80 ). The effect size and statistical power analyses appear to suggest the rejection of the null hypothesis was not erroneous, 
and subsequently that the impact of the online prep chem course on student performance relative to the previous in-person course was significant.

Because the prep chem course was populated with students who scored lower on the campuswide math placement exam, it was necessary to determine if the online prep chem course might not be as effective for the least academically prepared students. In order to determine how the online course impacted these students, the lowest quartile of students from the F18 and F17 cohorts, as determined by math SAT scores, were evaluated in separate multiple linear regression analyses (see Tables 5 and 6). The results from these analyses suggest the online prep chem course may have been more beneficial to the least academically prepared students compared to the entire class population. On average, students in the F18 online prep chem course scored 11 points higher on the prep chem final exam score than their counterparts in the F17 in-person course (unstandardized $B=11.103 ; p<0.001$; see Table 5). The least academically prepared students also appeared to perform better in the subsequent general chemistry CHEM 001A course, as the F18 online prep chem students earned grades that were on average, 0.32 GPA quality points higher than the students in the F17 in-person course (unstandardized $B=0.323 ; p=0.001$; see Table 6 ). Because the sample sizes were significantly smaller for these populations (F18 cohort: $\mathrm{n}=96 ; \mathrm{F} 17$ cohort: $n=120$ ), the effect sizes and statistical power for these analyses were also calculated. The $\mathrm{f}^{2}$ effect sizes were 0.200 and 0.0469 for the prep chem final exam score and CHEM 001A course grade analyses, respectively (see Supplemental Tables 5 and 6). These effect sizes can be categorized as medium and small for the prep chem final exam scores and CHEM 001A course grades, respectively. Because these populations were smaller in number, there was a chance these analyses would have reduced statistical power. The statistical power for prep chem final exam score analysis was calculated to be 0.96 (see Supplemental Table 5), whereas the statistical power for the CHEM 001A course grade analysis was determined to be 0.35 (see Supplemental Table 6). Though the unstandardized $B$ coefficients for the class participation independent variable was found to be statistically significant for both analyses, it appears there is a greater chance the null hypothesis might have been erroneously rejected for the CHEM 001A analysis. These results suggest the online prep chem course at the very least did not adversely affect the least academically prepared students in the subsequent general chemistry course compared to the previous in-person prep chem course. 
Table 5: Multiple Linear Regression of the Lowest Quartile Student Population. Independent variable (group) = class participation $(1=$ online, $0=$ in-person $)$; dependent variable $=$ final exam grade (expressed a percentage); F18 online prep chem course: $n=96$; F17 in-person course: $n=120$ ). ${ }^{a}$

\begin{tabular}{|c|c|c|c|c|c|c|c|}
\hline \multirow[b]{2}{*}{ Model } & \multicolumn{2}{|c|}{$\begin{array}{l}\text { Unstandardized } \\
\text { Coefficients }\end{array}$} & \multirow{2}{*}{$\begin{array}{c}\begin{array}{c}\text { Standardized } \\
\text { Coefficients }\end{array} \\
\text { Beta }\end{array}$} & \multirow[b]{2}{*}{$t$} & \multirow[b]{2}{*}{$p$} & \multicolumn{2}{|c|}{$\begin{array}{l}\text { 95.0\% Confidence } \\
\text { Interval for } \boldsymbol{B}\end{array}$} \\
\hline & $B$ & $\begin{array}{l}\text { Std. } \\
\text { Error }\end{array}$ & & & & $\begin{array}{l}\text { Lower } \\
\text { Bound }\end{array}$ & $\begin{array}{l}\text { Upper } \\
\text { Bound }\end{array}$ \\
\hline (Constant) & 19.587 & 21.391 & & 0.916 & 0.361 & -22.580 & 61.754 \\
\hline $\begin{array}{l}\text { Group }(1=\mathrm{W} 18 \text { online; } \\
0=\mathrm{W} 17 \text { in-person })\end{array}$ & 11.103 & 1.701 & 0.408 & 6.527 & $<0.001$ & 7.750 & 14.456 \\
\hline HS_GPA & 8.826 & 3.912 & 0.141 & 2.256 & 0.025 & 1.113 & 16.538 \\
\hline SAT_MATH & 0.026 & 0.029 & 0.055 & 0.900 & 0.369 & -0.031 & 0.082 \\
\hline
\end{tabular}

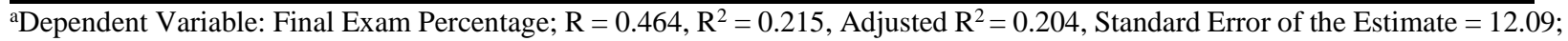
$\mathrm{f}^{2}$ effect size $=0.200$.

Table 6: Multiple Linear Regression of the Lowest Quartile Student Population. Independent variable (group) $=$ class participation $(1=$ online, $0=$ in-person); dependent variable $=$ course grade (expressed as $0-4$ GPA-quality point); F18 online prep chem course: $n=96$; F17 in-person course: $n=120$. ${ }^{a}$

\begin{tabular}{|c|c|c|c|c|c|c|c|}
\hline \multirow[b]{2}{*}{ Model } & \multicolumn{2}{|c|}{$\begin{array}{l}\text { Unstandardized } \\
\text { Coefficients }\end{array}$} & \multirow{2}{*}{$\begin{array}{c}\text { Standardized } \\
\text { Coefficients }\end{array}$} & \multirow[b]{2}{*}{$t$} & \multirow[b]{2}{*}{$p$} & \multicolumn{2}{|c|}{$\begin{array}{l}\text { 95.0\% Confidence } \\
\text { Interval for } \boldsymbol{B}\end{array}$} \\
\hline & $\boldsymbol{B}$ & $\begin{array}{l}\text { Std. } \\
\text { Error }\end{array}$ & & & & $\begin{array}{l}\text { Lower } \\
\text { Bound }\end{array}$ & $\begin{array}{l}\text { Upper } \\
\text { Bound }\end{array}$ \\
\hline (Constant) & $\begin{array}{c}- \\
0.468\end{array}$ & 1.279 & & -0.366 & 0.715 & -2.989 & 2.053 \\
\hline $\begin{array}{l}\text { Group }(1=\mathrm{W} 18 \text { online; } 0 \\
=\mathrm{W} 17 \text { in-person })\end{array}$ & 0.323 & 0.102 & 0.215 & 3.180 & 0.002 & 0.123 & 0.524 \\
\hline HS_GPA & 0.465 & 0.234 & 0.134 & 1.990 & 0.048 & 0.004 & 0.927 \\
\hline SAT_MATH & 0.002 & 0.002 & 0.083 & 1.255 & 0.211 & -0.001 & 0.006 \\
\hline
\end{tabular}

${ }^{a}$ Dependent Variable: GPA Quality Point Dependent Variable, b. $R=0.290, R^{2}=0.084$, Adjusted $R^{2}=0.071$, Standard Error of the Estimate $=0.723 ; \mathrm{f}^{2}$ effect size $=0.0469$.

Analogous to the full class analyses, linear regression models were also created in which gender and ethnic identity were included as independent variables (see Supplemental Tables 7 and 8). 
These covariates did not appear to have a significant relationship to the prep chem final exam scores or CHEM 001A course grades for the lowest quartile of students, as none of these independent variables had unstandardized $B$ coefficients that were significant at the $p=0.05$ level. As was observed in the full class analysis, the explanatory power of neither model improved significantly when the gender and ethnic identity variables were included (i.e., the adjusted $\mathrm{R}^{2}$ did not increase significantly when these additional independent variables were included in the model; see Supplemental Tables 7 and 8), therefore the models described in Tables 5 and 6 were used in the final analysis.

\section{DISCUSSION}

\section{Impact of Asynchronous Online Prep Chem}

Overall, the asynchronous online prep chem course appears to not only perform on par with the analogous in-person course, but likely led to even greater improvement in both the prep chem final exam scores and course grades in the subsequent general chemistry course. The positive impact on student performance that appeared to arise from the F18 online prep chem course corroborates findings from previous studies of prep chem interventions. As mentioned in the introduction, Botch and coworkers reported that a 20-hour self-paced series of online modules improved student success rates and course grades in the subsequent general chemistry course, ${ }^{1}$ and the report from Dockter and coworkers suggested a self-paced prep chem experience based on the ALEKS online learning system also led to greater student performance in the subsequent general chemistry course relative to the traditional in-person prep chem course. ${ }^{3}$ The question that arises then, is how are students able to make significant performance gains in these asynchronous online learning environments? The findings reported herein are particularly noteworthy in this regard, given the fact students in the online prep chem appeared to outperform students from the previous in-person course that had associated with it an additional 120-minute weekly discussion group section (which was not included in the online course.) The general success of these online self-paced prep chem experiences is most likely linked to their ability to reduce cognitive load for students and help mitigate the inherent limitations in working memory capacity. ${ }^{12}$ Taking course content typically delivered in a 50-minute lecture and allowing students to engage in this material over a longer period of time, and/or review the material multiple times, should result in a more effective integration of new knowledge into long term memory. One particular advantage of the F18 prep 
chem course described here was the fact it was structured as a for-credit course in the regular academic term, rather than an optional summer bridge or pre-term preparatory experience. This not only helped ensure higher participation rates compared to the more targeted prep chem implementations described by Botch and Dockter, but also provided more time for students to complete the online modules. Spreading out the online modules over a 10-week quarter likely reduced the cognitive demand in the F18 prep chem course as opposed to the typical summer bridge or pre-term preparatory course (the ChemPrep modules described by Botch, et al. were done over a 20 -hour period; ${ }^{1}$ the ALEKS summer prep described by Dockter, et al. was done over a summer term, though the length of the term was not stated in that report ${ }^{3}$ ). It is imperative to note that one major limitation in this analysis lies with the fact the impact of the online prep chem course on student general chemistry grades was not able to control for instructor variability in the subsequent CHEM 001A course. If the F18 and F17 prep chem cohorts had distinctly different learning experiences in CHEM 001A due to instructor effectiveness, this could have led to the difference in course grades predicted by the linear regression models. Despite this limitation, the fact the F18 online prep chem course appeared to significantly outperform the F17 in-person course on the prep chem final exam suggests the online course likely had some impact on the CHEM 001A course grades.

It was stated in the introduction that Mayer suggests the online learning environment should aim to reduce extraneous processing, manage essential processing, and foster generative processing. ${ }^{12}$ Upon review of the F18 online learning materials, the learning glass lecture videos and online quizzes adhered to the guidelines proposed by Mayer reasonably well. In particular, the videos were segmented into several 10-15 minute videos that could be viewed by the students at their own pace, rather than one 50-60 minute live synchronous online lecture. By segmenting the essential course content and allowing students to self-pace their work, this likely managed essential processing and reduced cognitive load. Secondly, most of the videos included practice problems for which students were encouraged to stop the video and complete on their own before proceeding through the rest of the tutorial. This structure provided students an opportunity to make sense of the material being taught in the tutorial, and likely fostered generative processing. Conversely, the learning glass videos employed in the F18 online prep chem course likely had a design flaw that may have led to an increase in extraneous processing. Mayer posits that students can simultaneously engage an auditory and visual channel in a multimedia learning environment, 
however if one of these channels is overloaded, it can result in cognitive overload and adversely affect the instructional objective. ${ }^{12}$ The snapshot depicted in Figure 1 illustrates the learning glass picture-in-picture feature which allowed the opportunity to embed figures and text into the video. This might seem to be a feature that enhances the production value of the video, however, providing the picture-in-picture text along with the live drawing/sketching on the learning glass likely overloaded the visual channel for students to some extent. This is certainly a design feature that needs to be more carefully thought out in future implementations of the online prep chem course. Despite this potential design flaw, considering the overall benefits of asynchronous online learning within the context of the cognitive theory of multimedia learning should make the results of the current and previous online prep chem interventions less surprising. If students are properly incentivized, either via course credit or on-time placement into general chemistry, and if the online learning environment is designed using the principles laid out in Mayer's cognitive theory of multimedia learning, institutions are likely to see the same types of performance improvements described in the current report.

Though cognitive load theory is likely a major contributor to the success of these online prep chem interventions, it is necessary to acknowledge the types of learning outcomes that are generally associated with these courses also potentially play a role in the observed improvement in student performance. For instance, the F18 online prep chem course described in the present study included learning objectives that would be considered zero- or one-dimensional skill-based learning objectives, as defined by the three-dimensional learning assessment protcol. ${ }^{22}$ Because these types of learning objectives do not require more sophisticated conceptual understanding or linking of multiple concepts, it is possible these skill-based learning objectives are more readily achieved in an asynchronous online learning environment. Upon reviewing the prep chem implementations of Botch, et al. and Dockter, et al., it seems these previous interventions also focused on skill-based learning objectives such as math skills, algorithmic problem-solving, measurement and dimensional analysis, stoichiometric calculations, basic atomic theory, and naming chemical compounds., ${ }^{1,3}$ If two- or three-dimensional learning objectives were to be included in an online prep chem course, it is possible designing an online learning environment that leads to positive outcomes might be more challenging for instructors. For instance, one could imagine the difficulty in fostering generative processing in an asynchronous online learning environment for learning objectives that involve cross-cutting concepts and/or deeper conceptual 
understanding of core content knowledge. How would students articulate this type of understanding and how could instructors provide feedback on this type of thinking in an asynchronous online environment? These are certainly questions that need to be answered if the scope of online prep chem courses expands beyond lower-dimensional skill-based learning objectives.

\section{Broader Implications of Online Instruction and Conclusions}

Given the apparent success of the asynchronous online prep chem course described herein, chemistry educators might consider applying this type of instruction more broadly to other undergraduate chemistry courses. As described above, the cognitive theory of multimedia learning suggest there are distinct advantages to well-designed asynchronous online learning environments relative to traditional in-person classes. These advantages would likely be amplified when comparing online learning to large enrollment courses that rely heavily on traditional didactic lecture, and in which theater-style auditoriums make it difficult to facilitate dialogic discussion. With that said, caution must be taken in extrapolating the positive impacts on student performance from online prep chem courses to other courses such as general chemistry or organic chemistry. These core courses in the chemistry undergraduate curriculum require deep understanding of the particulate nature of matter, how matter can be conceived of in different representations, and how molecular or sub-microscopic properties are connected to macro-scale phenomena. ${ }^{23}$ Achieving meaningful learning within these contexts will likely be more difficult to achieve using asynchronous online delivery compared to the lower order learning objectives encompassed in most prep chem courses. Mayer notes the research on multimedia learning needs to be expanded to gain insight about what type of interventions will work best to promote conceptual learning versus algorithmic problem solving, and longer-term transfer of knowledge versus knowledge retention. ${ }^{12}$ Additionally, though the results from the analysis including the lowest quartile of students suggest the F18 online prep chem did not adversely affect this population of students, future studies should aim to determine if academically less-prepared students can make learning gains with higher order learning objectives. If the educational research can help create a blueprint for practitioners in regards to what types of instructional designs can help different types of learners engage with different dimensions of learning objectives, online learning can begin to impact a broader portion of the undergraduate chemistry curriculum. 
The implementation of online instruction is often driven by external pressures such as limits in classroom space, lack of instructional personnel, and/or the desire of colleges and universities to expand their enrollments beyond the typical residential full-time student. The results presented herein add to the existing literature that suggests online courses actually improve student performance outcomes relative to equivalent in-person courses, and therefore should be offered for this more intrinsic reason. Because it was found the fully online asynchronous prep chem course appears to improve student performance outcomes, both in the prep chem course itself and in the subsequent general chemistry course, more chemistry departments at institutions of higher learning should strongly consider developing similar online prep chem courses. Most importantly, the post-hoc analysis presented here also revealed the least academically prepared students in the course appeared to make even greater performance gains than the entire classroom population. This suggests using an asynchronous online prep chem course has the potential to help lessprepared students succeed in general chemistry, ultimately improving retention in STEM disciplines.

\section{ASSOCIATED CONTENT}

\section{Supporting Information}

The Supporting Information is available on the ACS Publications website at DOI:xxx/acs.jchemed.xxx.

F17 In-person Prep Chem Syllabus (PDF)

F18 In-person Prep Chem Syllabus (PDF)

Supplemental Data Tables (PDF)

\section{AUTHOR INFORMATION}

\section{Corresponding Author}

*E-mail: jack.eichler@ucr.edu 


\section{CITED REFERENCES}

1. Botch, B.; Day, R.; Vining, W.; Stewart, B.; Hart, D.; Rath, K.; Peterfreund, A. Effects on student achievement in general chemistry following participation in an online preparatory course: ChemPrep, a voluntary, self-paced, online introduction to chemistry. J. Chem. Educ., 2007, 84 (3), 547.

2. Bayer Corporation. Bayer facts of science education XV: A view from the gatekeepers-STEM department chairs at America's top 200 research universities on female and underrepresented minority undergraduate STEM students. J. Sci. Educ. Technol. 2012, 21, 317-324.

3. Dockter, D.; Uvarov, C.; Guzman-Alvarez, A.; Molinaro, M. Improving preparation and persistence in undergraduate STEM: Why an online summer preparatory chemistry course makes sense. Sörensen and Canelas (eds.), Online Approaches to Chemical Education, ACS Symposium Series; American Chemical Society: Washington, DC, 2017.

4. Catalog. University of California Cross-Campus Enrollment; View All Courses. http://crossenrollcourses.universityofcalifornia.edu/catalog?subject_area=7\&with_preview=\&pa geSize $=10$ (last accessed March 13, 2020).

5. Eitemüller, C.; Habig, S. Enhancing the transition? Effects of a tertiary bridging course in chemistry. Chem. Educ. Res. Pract., 2020, DOI: 10.1039/c9rp00207c.

6. Schmid S.; Youl D. J.; George A. V.; Read J. R. Effectiveness of a short, intensive bridging course for scaffolding students commencing university-level study of chemistry, Int. J. Sci. Educ., 2012, 34 (8), 1211-1234.

7. Smith Falk, A.; Guzman-Alvarez, A.; Molinaro, M. Understanding the curve: Implications of norm-referenced grading in large introductory science courses. In poster presented at the Society for Teaching and Learning in Higher Education conference, Vancouver, BC, 2015.

8. Myers, C. B.; Bennett, D.; Brown, G.; Henderson, T. Emerging online learning environments and student learning: An analysis of faculty perceptions. Educ. Tech. Soc., 2004, 7 (1), 78-86. 
9. Williams, S.L. The effectiveness of distance education in allied health science programs: A meta-analysis of outcomes, Amer. J. Dist. Educ., 2006, 20 (3), 127-141.

10. Shachar, M.; Neumann, Y. Differences between traditional and distance education academic performances: A meta-analytic approach, Int. Rev. Res. Open Distrib. Learn., 2003, 4 (2), 153.

11. Faulconer, E. K.; Griffith, J. C.; Wood, B. L.; Acharyya, S.; Roberts, D. L. A comparison of online and traditional chemistry lecture and lab. Chem. Educ. Res. Pract., 2018, 19 (1), 392-397.

12. Mayer, R.E. In The Psychology of Leaning and Motivation: Cognition in Education, 2011, Vol. 55. Mestre, J.P.; Ross, B.H. (eds.), Academic Press, San Diego, CA.

\section{Learning Glass Solutions:}

https://www.learning.glass/product-line/?gclid=EAIaIQobChMIwrzjzMiY6AIVZxitBh3vUgnEAAYASAAEgJ2fvD_BwE (last accessed March 13, 2020).

14. ProctorU: https://www.proctoru.com/ (last accessed March 13, 2020).

15. OpenStax General Chemistry: https://openstax.org/details/books/chemistry-2e (last accessed March, 13, 2020).

16. Murnane, R.J.; Willett, J.B. In: Methods Matter: Improving Causal Inference Educational and Social Science Research; Bassett, J., Ed.; Oxford University Press: New York, NY, 2011; Volume $1,286-332$.

17. 2IBM Corp. Released 2016. IBM SPSS Statistics for Windows, Version 24.0. Armonk, NY: IBM Corp.

18. Cohen J., 1988, Statistical Power Analysis for the Behavioral Sciences, 2nd edn, New York, NY: Lawrence Erlbaum Associates, ch. 9. 
19. https://ir.ucr.edu/stats/enroll/demographic (last accessed March 13, 2020).

20. Vincent-Ruz, P., Binning, K., Schunn, C.D., Grabowski, J. The Effect of Math SAT on Women's Chemistry Competency Beliefs. Chem. Educ. Res. Pract., 2018, 19, 342-351.

21. Zwick, R., \& Sklar, J.C. Predicting College Grades and Degree Completion Using High School Grades and SAT Scores: The Role of Student Ethnicity and First Language. Amer. Educ. Res. Jour., 2005, 42, 439-464.

22. Laverty, J. T.; Underwood, S. M.; Matz, R. L.; Posey, L. A.; Carmel, J. H.; Caballero, M. D.; Fata-Hartley, C. L.; Ebert-May, D.; Jardeleza, S. E.; Cooper, M. M. Characterizing College Science Assessments: The Three-Dimensional Learning Assessment Protocol. PLoS One, 2016, 11, $\mathrm{e} 0162333$.

23. Johnstone, A. H. You Can't Get There from Here. J. Chem. Educ., 2010, 87 (1), $22-29$. 


\section{Supplemental Information}

Supplemental Table 1: Multiple linear regression analysis determining the impact of course participation on prep chem final exam score for the total student population. Independent variable ("group") $=$ class participation (online = 1, in-person $=0$ ); dependent variable $=$ prep chem final exam score (final exam scores were reported as scores out 100 points). Model includes gender and ethnicity independent variables; F18 online prep chem course: $n=463$; F17 inperson course: $\mathrm{n}=408{ }^{\mathrm{a}}$

\begin{tabular}{|c|c|c|c|c|c|c|c|}
\hline \multirow[b]{2}{*}{ Independent Variable } & \multicolumn{2}{|c|}{$\begin{array}{l}\text { Unstandardized } \\
\text { Coefficients }\end{array}$} & \multirow{2}{*}{$\begin{array}{c}\begin{array}{c}\text { Standardized } \\
\text { Coefficients }\end{array} \\
\text { Beta }\end{array}$} & \multirow[b]{2}{*}{$t$} & \multirow[b]{2}{*}{$p$} & \multicolumn{2}{|c|}{$\begin{array}{l}95.0 \% \text { Confidence } \\
\text { Interval for } B\end{array}$} \\
\hline & $B$ & $\begin{array}{l}\text { Std. } \\
\text { Error }\end{array}$ & & & & Lower Bound & Upper Bound \\
\hline (Constant) & 48.84 & 9.728 & & 5.02 & $<0.001$ & 29.745 & 67.934 \\
\hline Group & 8.637 & 0.814 & 0.342 & 10.615 & $<0.001$ & 7.04 & 10.235 \\
\hline HS_GPA & 3.608 & 1.688 & 0.071 & 2.137 & 0.033 & 0.295 & 6.922 \\
\hline SAT_MATH & 0.027 & 0.007 & 0.132 & 3.809 & $<0.001$ & 0.013 & 0.042 \\
\hline $\begin{array}{l}\text { Gender }(1=\text { female } ; 0= \\
\text { male })\end{array}$ & -2.375 & 5.214 & -0.09 & -0.456 & 0.649 & -12.609 & 7.858 \\
\hline ASIAN $(1=$ Asian; $0=$ else $)$ & -4.288 & 7.056 & -0.161 & -0.608 & 0.544 & -18.138 & 9.561 \\
\hline $\begin{array}{l}\text { BLACK OR AFRICAN } \\
\text { AMERICAN }(1=\text { African } \\
\text { American; } 0=\text { else })\end{array}$ & -2.711 & 7.469 & -0.033 & -0.363 & 0.717 & -17.371 & 11.949 \\
\hline $\begin{array}{l}\text { HISPANIC OR LATIN } \\
\text { AMERICAN ( } 1=\text { Hispanic; } \\
0=\text { else })\end{array}$ & -6.195 & 6.995 & -0.245 & -0.886 & 0.376 & -19.925 & 7.535 \\
\hline $\begin{array}{l}\text { MULTI-RACIAL }(1= \\
\text { Multi-racial; } 0=\text { else })\end{array}$ & -4.039 & 7.204 & -0.076 & -0.561 & 0.575 & -18.179 & 10.101 \\
\hline $\begin{array}{l}\text { NATIVE HAWAIIAN OR } \\
\text { OTHER PACIFIC } \\
\text { ISLANDER ( } 1 \text { = Native } \\
\text { Hawaiian/Pacific Islander; } 0 \\
=\text { else })\end{array}$ & -13.739 & 10.767 & -0.052 & -1.276 & 0.202 & -34.872 & 7.393 \\
\hline $\begin{array}{l}\text { NON-RESIDENT ALIEN ( } 1 \\
=\text { non-resident; } 0=\text { else })\end{array}$ & 2.897 & 9.683 & 0.014 & 0.299 & 0.765 & -16.109 & 21.902 \\
\hline $\begin{array}{l}\text { WHITE }(1=\text { White; } 0= \\
\text { else })\end{array}$ & -4.284 & 7.114 & -0.108 & -0.602 & 0.547 & -18.248 & 9.679 \\
\hline
\end{tabular}

a. $\mathrm{R}=0.417 ; \mathrm{R}^{2}=0.174 ;$ Adjusted $\mathrm{R}^{2}=0.162 ;$ Standard Error of the Estimate $=11.52688 ; \mathrm{f}^{2}$ effect size $=0.133$ (see Supplemental Table 1 for effect size and estimated power calculations). 
Supplemental Table 2: Multiple linear regression analysis determining the impact of course participation on general chemistry course grade for the total student population (general chemistry was taken in the subsequent quarter after the prep chem course). Independent variable ("group") = class participation (online = 1, in-person = 0); dependent variable $=$ course grade $($ expressed as 0-4 GPA quality point). Model includes gender and ethnicity independent variables; F18 online prep chem course: $n=463$; F17 in-person course: $n=408 .^{a}$

\begin{tabular}{|c|c|c|c|c|c|c|c|}
\hline \multirow[b]{2}{*}{ Independent Variable } & \multicolumn{2}{|c|}{$\begin{array}{l}\text { Unstandardized } \\
\text { Coefficients }\end{array}$} & \multirow{2}{*}{$\begin{array}{c}\begin{array}{c}\text { Standardized } \\
\text { Coefficients }\end{array} \\
\text { Beta }\end{array}$} & \multirow[b]{2}{*}{$t$} & \multirow[b]{2}{*}{$p$} & \multicolumn{2}{|c|}{$\begin{array}{l}\text { 95.0\% Confidence } \\
\text { Interval for } B\end{array}$} \\
\hline & $\boldsymbol{B}$ & $\begin{array}{l}\text { Std. } \\
\text { Error }\end{array}$ & & & & $\begin{array}{l}\text { Lower } \\
\text { Bound }\end{array}$ & $\begin{array}{l}\text { Upper } \\
\text { Bound }\end{array}$ \\
\hline (Constant) & -0.968 & 0.600 & & -1.613 & 0.107 & -2.145 & 0.210 \\
\hline Group & 0.269 & 0.050 & 0.179 & 5.363 & $<0.001$ & 0.171 & 0.368 \\
\hline HS_GPA & 0.479 & 0.104 & 0.158 & 4.598 & $<0.001$ & 0.274 & 0.683 \\
\hline SAT_MATH & 0.002 & 0.000 & 0.189 & 5.280 & $<0.001$ & 0.001 & 0.003 \\
\hline Gender $(1=$ female $; 0=$ male $)$ & -0.273 & 0.322 & -0.172 & -0.848 & 0.397 & -0.904 & 0.358 \\
\hline $\operatorname{ASIAN}(1=$ Asian; $0=$ else $)$ & 0.778 & 0.435 & 0.489 & 1.788 & 0.074 & -0.076 & 1.632 \\
\hline $\begin{array}{c}\text { BLACK OR AFRICAN } \\
\text { AMERICAN }(1=\text { African } \\
\text { American; } 0=\text { else })\end{array}$ & 0.765 & 0.461 & 0.157 & 1.662 & 0.097 & -0.139 & 1.669 \\
\hline $\begin{array}{c}\text { HISPANIC OR LATIN } \\
\text { AMERICAN }(1=\text { Hispanic; } 0= \\
\text { else })\end{array}$ & 0.639 & 0.431 & 0.423 & 1.481 & 0.139 & -0.208 & 1.485 \\
\hline $\begin{array}{c}\text { MULTI-RACIAL ( } 1=\text { Multi-racial; } \\
0=\text { else })\end{array}$ & 0.846 & 0.444 & 0.265 & 1.905 & 0.057 & -0.026 & 1.718 \\
\hline $\begin{array}{l}\text { NATIVE HAWAIIAN OR OTHER } \\
\text { PACIFIC ISLANDER }(1=\text { Native } \\
\text { Hawaiian/Pacific Islander; } 0=\text { else })\end{array}$ & 0.588 & 0.664 & 0.038 & 0.886 & 0.376 & -0.715 & 1.891 \\
\hline $\begin{array}{l}\text { NON-RESIDENT ALIEN }(1= \\
\text { non-resident; } 0=\text { else })\end{array}$ & 0.623 & 0.597 & 0.049 & 1.044 & 0.297 & -0.549 & 1.795 \\
\hline WHITE $(1=$ White; $0=$ else $)$ & 0.714 & 0.439 & 0.303 & 1.628 & 0.104 & -0.147 & 1.575 \\
\hline
\end{tabular}

a. $\mathrm{R}=0.344 ; \mathrm{R}^{2}=0.118$; Adjusted $\mathrm{R}^{2}=0.106$; Standard Error of the Estimate $=0.71078 ; \mathrm{f}^{2}$ effect size $=0.033$ (see Supplemental Table 2 for effect size and estimated power calculations). 
Supplemental Table 3: Power Analysis of the Full Class Cohort with Final Exam Percentage Dependent Variable: Multiple regression analysis carried out for the post-hoc power analysis, in which the group independent variable was removed. The difference in $\mathrm{R}^{2}$ compared to the full model was used to estimate the $\mathrm{f}^{2}$ effect size index; $\mathrm{f}^{2}=$ change in $\mathrm{R}^{2} /\left(1-\mathrm{R}^{2}\right)$. The function of the effect size index and the non-centrality parameter $(\lambda)$ was used to estimate the power from Cohen's power tables at $\alpha=0.05$ (Table 9.3.2, Cohen, 1988); $\lambda=\mathrm{f}^{2}(\mathrm{u}+\mathrm{v}+1)$ where $\mathrm{u}=\#$ independent variables in the model and $\mathrm{v}=$ degrees of freedom $(\mathrm{v}=\mathrm{N}-\mathrm{u}-\mathrm{w}-1) ; \mathrm{N}=$ sample size and $\mathrm{w}=\#$ independent variables in the model without the treatment independent variable. $\mathrm{f}^{2}=(0.160-0.049) /(1-0.160)=0.132 ; \mathrm{v}=(463$ $3-2-1)=457 ; \lambda=0.132(3+457+1)=60.8$; therefore if $\mathrm{u}=3, \lambda=60.8$, and $\mathrm{v}=457$ the power is estimated to be $>0.995$. $^{\mathrm{a}}$

\begin{tabular}{|c|c|c|c|c|c|}
\hline \multirow[b]{2}{*}{ Model } & \multicolumn{2}{|c|}{$\begin{array}{l}\text { Unstandardized } \\
\text { Coefficients }\end{array}$} & \multirow{2}{*}{$\begin{array}{c}\begin{array}{c}\text { Standardized } \\
\text { Coefficients }\end{array} \\
\text { Beta }\end{array}$} & \multirow[b]{2}{*}{$t$} & \multirow[b]{2}{*}{$p$} \\
\hline & $B$ & Std. Error & & & \\
\hline (Constant) & 23.140 & 10.189 & & 2.703 & 0.007 \\
\hline HS_GPA & 7.023 & 1.743 & 0.139 & 4.029 & $<0.001$ \\
\hline SAT_MATH & 0.045 & 0.007 & 0.213 & 6.204 & $<0.001$ \\
\hline
\end{tabular}

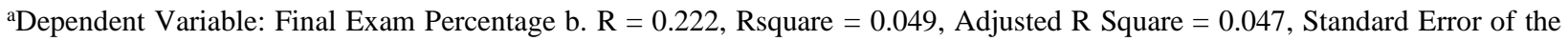
Estimate $=12.29$.

Supplemental Table 4: Power Analysis of the Full Class Cohort with GPA Quality Point Dependent Variable. Multiple regression analysis carried out for the post-hoc power analysis, in which the group independent variable was removed. The difference in $\mathrm{R}^{2}$ compared to the full model was used to estimate the $\mathrm{f}^{2}$ effect size index; $\mathrm{f}^{2}=$ change in $\mathrm{R}^{2} /\left(1-\mathrm{R}^{2}\right)$. The function of the effect size index and the non-centrality paramater $(\lambda)$ was used to estimate the power from Cohen's power tables at $\alpha=0.05$ (Table 9.3.2, Cohen, 1988); $\lambda=\mathrm{f}^{2}(\mathrm{u}+\mathrm{v}+1)$ where $\mathrm{u}=$ \# independent variables in the model and $\mathrm{v}=$ degrees of freedom $(\mathrm{v}=\mathrm{N}-\mathrm{u}-\mathrm{w}-1) ; \mathrm{N}=$ sample size and $\mathrm{w}=\#$ independent variables in the model without the group independent variable. $\mathrm{f}^{2}=(0.103-0.073) /(1-0.103)=0.0334 ; \mathrm{v}=(463-3-2-1)=457$; $\lambda=0.0334(3+457+1)=15.4$; therefore if $\mathrm{u}=3, \lambda=15.4$, and $\mathrm{v}=457$ the power is estimated to $\mathrm{be} \approx 0.91$. $^{\mathrm{a}}$

\begin{tabular}{|c|c|c|c|c|c|}
\hline \multirow[b]{2}{*}{ Model } & \multicolumn{2}{|c|}{$\begin{array}{l}\text { Unstandardized } \\
\text { Coefficients }\end{array}$} & \multirow{2}{*}{$\begin{array}{c}\begin{array}{c}\text { Standardized } \\
\text { Coefficients }\end{array} \\
\text { Beta }\end{array}$} & \multirow[b]{2}{*}{$t$} & \multirow[b]{2}{*}{$p$} \\
\hline & $\boldsymbol{B}$ & Std. Error & & & \\
\hline (Constant) & -1.051 & 0.505 & & -2.083 & 0.038 \\
\hline HS_GPA & 0.542 & 0.103 & 0.179 & 5.273 & $<0.001$ \\
\hline SAT_MATH & 0.003 & 0.000 & 0.254 & 7.474 & $<0.001$ \\
\hline
\end{tabular}

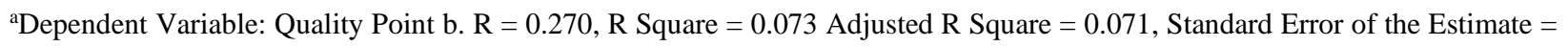
0.725 . 
Supplemental Table 5: Power Analysis of the Lowest Quartile Cohort with Final Exam Percentage Dependent Variable. Multiple regression analysis carried out for the post-hoc power analysis, in which the group independent variable was removed. The difference in $\mathrm{R}^{2}$ compared to the full model was used to estimate the $\mathrm{f}^{2}$ effect size index; $\mathrm{f}^{2}=$ change in $\mathrm{R}^{2} /\left(1-\mathrm{R}^{2}\right)$. The function of the effect size index and the non-centrality paramater $(\lambda)$ was used to estimate the power from Cohen's power tables at $\alpha=0.05$ (Table 9.3.2, Cohen, 1988); $\lambda=\mathrm{f}^{2}(\mathrm{u}+\mathrm{v}+1)$ where $\mathrm{u}=\#$ independent variables in the model and $\mathrm{v}=$ degrees of freedom $(\mathrm{v}=\mathrm{N}-\mathrm{u}-\mathrm{w}-1) ; \mathrm{N}=$ sample size and $\mathrm{w}=\#$ independent variables in the model without the group independent variable. $\mathrm{f}^{2}=(0.215-0.058) /(1-0.215)=0.200 ; \mathrm{v}=(96-3-2$ $-1)=90 ; \lambda=0.200(3+90+1)=18.8$; therefore if $\mathrm{u}=3, \lambda=18.8$, and $\mathrm{v}=90$ the power is estimated to be $\approx 0.96$. ${ }^{\mathrm{a}}$

\begin{tabular}{|c|c|c|c|c|c|}
\hline \multirow{2}{*}{ Model } & \multicolumn{2}{|c|}{$\begin{array}{l}\text { Unstandardized } \\
\text { Coefficients }\end{array}$} & \multirow{2}{*}{$\begin{array}{c}\begin{array}{c}\text { Standardized } \\
\text { Coefficients }\end{array} \\
\text { Beta }\end{array}$} & \multirow{2}{*}{$t$} & \multirow{2}{*}{$p$} \\
\hline & $\boldsymbol{B}$ & Std. Error & & & \\
\hline (Constant) & -6.768 & 22.967 & & -0.295 & 0.769 \\
\hline HS_GPA & 14.080 & 4.186 & 0.224 & 3.364 & 0.001 \\
\hline SAT_MATH & 0.048 & 0.031 & 0.104 & 1.558 & 0.121 \\
\hline
\end{tabular}

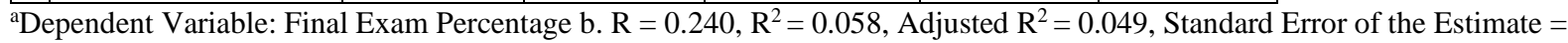
13.22 .

Supplemental Table 6: Power Analysis of the Lowest Quartile Cohort with GPA Quality Point Dependent Variable Multiple regression analysis carried out for the post-hoc power analysis, in which the group independent variable was removed. The difference in $R^{2}$ compared to the full model was used to estimate the $\mathrm{f}^{2}$ effect size index; $\mathrm{f}^{2}=$ change in $\mathrm{R}^{2} /\left(1-\mathrm{R}^{2}\right)$. The function of the effect size index and the non-centrality paramater $(\lambda)$ was used to estimate the power from Cohen's power tables at $\alpha=0.05$ (Table 9.3.2, Cohen, 1988); $\lambda=\mathrm{f}^{2}(\mathrm{u}+\mathrm{v}+1)$ where $\mathrm{u}=\#$ independent variables in the model and $\mathrm{v}=$ degrees of freedom $(\mathrm{v}=\mathrm{N}-\mathrm{u}-\mathrm{w}-1) ; \mathrm{N}=$ sample size and $\mathrm{w}=\#$ independent variables in the model without the group independent variable. $\mathrm{f}^{2}=(0.084-0.041) /(1-0.084)=$ $0.0469 ; \mathrm{v}=(96-3-2-1)=90 ; \lambda=0.0469(3+90+1)=4.41$; therefore if $\mathrm{u}=3, \lambda=4.41$, and $\mathrm{v}=90$ the power is estimated to $\mathrm{be} \approx 0.35$. $^{\mathrm{a}}$

\begin{tabular}{|c|c|c|c|c|c|}
\hline \multirow{2}{*}{ Model } & \multicolumn{2}{|c|}{$\begin{array}{c}\text { Unstandardized } \\
\text { Coefficients }\end{array}$} & \multirow{2}{*}{$\begin{array}{c}\begin{array}{c}\text { Standardized } \\
\text { Coefficients }\end{array} \\
\text { Beta }\end{array}$} & \multirow{2}{*}{$t$} & \multirow{2}{*}{$p$} \\
\hline & $\boldsymbol{B}$ & Std. Error & & & \\
\hline (Constant) & -1.236 & 1.283 & & -0.963 & 0.336 \\
\hline HS_GPA & 0.618 & 0.234 & 0.178 & 2.646 & 0.009 \\
\hline SAT_MATH & 0.003 & 0.002 & 0.109 & 1.619 & 0.107 \\
\hline
\end{tabular}

aDependent Variable: GPA Quality Point b. $\mathrm{R}=0.202, \mathrm{R}^{2}=0.041$, Adjusted $\mathrm{R}^{2}=0.032$, Standard Error of the Estimate $=0.738$. 
Supplemental Table 7: Multiple Linear Regression of the Lowest Quartile Student Population. Independent variable (group) $=$ class participation $($ online $=1$, in-person $=0)$; dependent variable $=$ final exam grade $($ expressed a percentage; F18 online prep chem course: $n=96$; F17 in-person course: $n=120$ ). Model includes gender and ethnicity independent variables. ${ }^{\text {a }}$

\begin{tabular}{|c|c|c|c|c|c|c|c|}
\hline \multirow[b]{2}{*}{ Model } & \multicolumn{2}{|c|}{$\begin{array}{c}\text { Unstandardized } \\
\text { Coefficients }\end{array}$} & \multirow{2}{*}{$\begin{array}{c}\text { Standardized } \\
\text { Coefficients } \\
\text { Beta }\end{array}$} & \multirow[b]{2}{*}{$t$} & \multirow[b]{2}{*}{$p$} & \multicolumn{2}{|c|}{$\begin{array}{l}95.0 \% \text { Confidence } \\
\text { Interval for } B\end{array}$} \\
\hline & B & $\begin{array}{l}\text { Std. } \\
\text { Error }\end{array}$ & & & & $\begin{array}{l}\text { Lower } \\
\text { Bound }\end{array}$ & $\begin{array}{l}\text { Upper } \\
\text { Bound }\end{array}$ \\
\hline (Constant) & 30.928 & 23.735 & & 1.303 & 0.194 & -15.871 & 77.726 \\
\hline Group & 11.763 & 1.712 & 0.432 & 6.872 & $<0.001$ & 8.388 & 15.138 \\
\hline HS_GPA & 10.217 & 3.955 & 0.163 & 2.583 & 0.010 & 2.419 & 18.014 \\
\hline SAT_MATH & 0.021 & 0.029 & 0.045 & 0.724 & 0.470 & -0.036 & 0.078 \\
\hline $\begin{array}{l}\text { Gender }(1=\text { female; } 0= \\
\text { male })\end{array}$ & $\begin{array}{c}- \\
12.256\end{array}$ & 12.078 & -0.374 & -1.015 & 0.311 & -36.068 & 11.557 \\
\hline $\begin{array}{l}\text { ASIAN }(1=\text { Asian; } 0= \\
\text { else })\end{array}$ & 0.815 & 14.800 & 0.026 & 0.055 & 0.956 & -28.366 & 29.996 \\
\hline $\begin{array}{l}\text { BLACK OR AFRICAN } \\
\text { AMERICAN }(1=\text { African } \\
\text { American; } 0=\text { else })\end{array}$ & -3.101 & 16.977 & -0.022 & -0.183 & 0.855 & -36.574 & 30.372 \\
\hline $\begin{array}{l}\text { HISPANIC OR LATIN } \\
\text { AMERICAN }(1= \\
\text { Hispanic; } 0=\text { else })\end{array}$ & -4.618 & 14.655 & -0.168 & -0.315 & 0.753 & -33.512 & 24.277 \\
\hline $\begin{array}{l}\text { MULTI-RACIAL }(1= \\
\text { Multi-racial; } 0=\text { else })\end{array}$ & -2.673 & 15.128 & -0.043 & -0.177 & 0.860 & -32.501 & 27.155 \\
\hline $\begin{array}{l}\text { NATIVE HAWAIIAN } \\
\text { OR OTHER PACIFIC } \\
\text { ISLANDER }(1=\text { Native } \\
\text { Hawaiian/Pacific Islander; } \\
0=\text { else })\end{array}$ & $\begin{array}{c}- \\
10.075\end{array}$ & 16.951 & -0.071 & -0.594 & 0.553 & -43.497 & 23.347 \\
\hline $\begin{array}{l}\text { WHITE }(1=\text { White; } 0= \\
\text { else })\end{array}$ & -1.661 & 14.952 & -0.035 & -0.111 & 0.912 & -31.142 & 27.819 \\
\hline
\end{tabular}

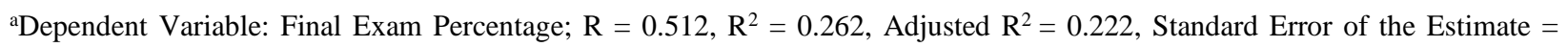
11.95298; $\mathrm{f}^{2}$ effect size $=0.232$. 
Supplemental Table 8: Multiple Linear Regression of the Lowest Quartile Student Population. Independent variable (group) $=$ class participation $($ online $=1$, in-person $=0)$; dependent variable $=$ course grade (expressed as 0-4 GPAquality point); F18 online prep chem course: $\mathrm{n}=96$; F17 in-person course: $\mathrm{n}=120$ ). Model includes gender and ethnicity independent variables. ${ }^{a}$

\begin{tabular}{|c|c|c|c|c|c|c|c|}
\hline \multirow[b]{2}{*}{ Model } & \multicolumn{2}{|c|}{$\begin{array}{l}\text { Unstandardized } \\
\text { Coefficients }\end{array}$} & \multirow{2}{*}{$\begin{array}{c}\text { Standardized } \\
\text { Coefficients } \\
\text { Beta }\end{array}$} & \multirow[b]{2}{*}{$t$} & \multirow[b]{2}{*}{$p$} & \multicolumn{2}{|c|}{$\begin{array}{l}95.0 \% \text { Confidence } \\
\text { Interval for } B\end{array}$} \\
\hline & B & $\begin{array}{l}\text { Std. } \\
\text { Error }\end{array}$ & & & & $\begin{array}{l}\text { Lower } \\
\text { Bound }\end{array}$ & $\begin{array}{l}\text { Upper } \\
\text { Bound }\end{array}$ \\
\hline (Constant) & -1.525 & 1.421 & & -1.073 & 0.284 & -4.326 & 1.276 \\
\hline Group & 0.341 & 0.102 & 0.227 & 3.333 & 0.001 & 0.139 & 0.543 \\
\hline HS_GPA & 0.602 & 0.237 & 0.173 & 2.542 & 0.012 & 0.135 & 1.068 \\
\hline SAT_MATH & 0.002 & 0.002 & 0.090 & 1.341 & 0.181 & -0.001 & 0.006 \\
\hline $\begin{array}{l}\text { Gender }(1=\text { female; } 0= \\
\text { male })\end{array}$ & -0.794 & 0.723 & -0.438 & -1.098 & 0.273 & -2.219 & 0.631 \\
\hline $\begin{array}{l}\text { ASIAN }(1=\text { Asian; } 0= \\
\text { else })\end{array}$ & 1.423 & 0.886 & 0.813 & 1.607 & 0.110 & -0.323 & 3.170 \\
\hline $\begin{array}{l}\text { BLACK OR AFRICAN } \\
\text { AMERICAN }(1= \\
\text { African American; } 0= \\
\text { else) }\end{array}$ & 1.127 & 1.016 & 0.144 & 1.109 & 0.269 & -0.876 & 3.130 \\
\hline $\begin{array}{l}\text { HISPANIC OR LATIN } \\
\text { AMERICAN }(1 \quad= \\
\text { Hispanic; } 0=\text { else })\end{array}$ & 1.091 & 0.877 & 0.716 & 1.244 & 0.215 & -0.639 & 2.820 \\
\hline $\begin{array}{l}\text { MULTI-RACIAL }(1= \\
\text { Multi-racial; } 0=\text { else })\end{array}$ & 1.246 & 0.905 & 0.366 & 1.376 & 0.170 & -0.539 & 3.031 \\
\hline $\begin{array}{l}\text { NATIVE HAWAIIAN } \\
\text { OR OTHER PACIFIC } \\
\text { ISLANDER }(1=\text { Native } \\
\text { Hawaiian/Pacific } \\
\text { Islander; } 0=\text { else })\end{array}$ & 1.163 & 1.015 & 0.149 & 1.147 & 0.253 & -0.837 & 3.164 \\
\hline $\begin{array}{l}\text { WHITE }(1=\text { White; } 0= \\
\text { else) }\end{array}$ & 1.118 & 0.895 & 0.423 & 1.250 & 0.213 & -0.646 & 2.883 \\
\hline
\end{tabular}

aDependent Variable: GPA Quality Point Dependent Variable, b. $R=0.370, R^{2}=0.137$, Adjusted $R^{2}=0.091$, Standard Error of the Estimate $=0.71537 ; \mathrm{f}^{2}$ effect size $=0.0545$. 
